\title{
Mesozoic Formations in
}

the Comobabi and Roskruge

Mountains, Papago Indian

Reservation, Arizona

By L. A. HEINDL

CONTRIBUTIONS TO STRATIGRAPHY

GEOLOGICAL SURVEY B ULLE T I N 1194-H

Prepared in cooperation

with the Bureau. of

Indian Affairs

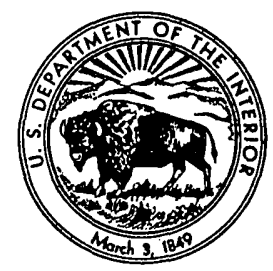




\title{
UNITED STATES DEPARTMENT OF THE INTERIOR
}

\author{
STEWART L. UDALL, Secretary
}

\section{GEOLOGICAL SURVEY}

Thomas B. Nolan, Director

U.S. GOVERNMENT PRINTING OFFICE, WASHINGTON : 1965

For sale by the Superintendent of Documents, U.S. Government Printing Office Washington, D.C. 20402 - Price 10 cents (paper cover) 


\section{CONTENTS}

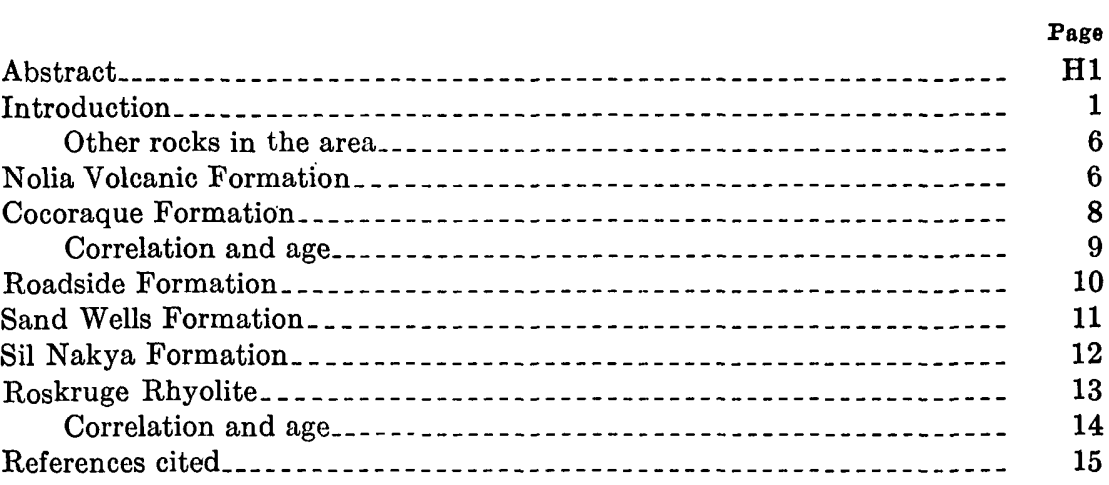

\section{ILLUSTRATIONS}

Figure 1. Map showing area of report
2. Sketch map showing generalized geology of Comobabi-Roskruge

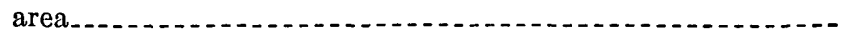





\title{
CONTRIBUTIONS TO STRATIGRAPHY
}

\section{MESOZOIG FORMATIONS IN THE COMOBABI AND ROSKRUGE MOUNTAINS, PAPAGO INDIAN RESERVATION, ARIZONA}

\author{
By L. A. Heinde
}

\begin{abstract}
Mesozoic deposits in the Comobabi and Roskruge Mountains, in ascending order, comprise the Nolia Volcanic Formation, consisting mostly of andesitic flows; the Cocoraque Formation, consisting mostly of arkosic and graywackish beds; the Roadside Formation, consisting of volcanic conglomerate, flows, and breccias; the Sand Wells Formation, consisting mostly of shale and shaley sandstone; and two possibly equivalent units, the Sil Nakya Formation and the Roskruge Rhyolite. The Sil Nakya Formation consists mostly of welded tuff and tuff-agglomerate, and the Roskruge Rhyolite consists mostly of rhyolitic flows, tuffs, and tuff-agglomerates. A complete section is nowhere exposed and the sequence is in part inferred. The composite section is between 20,000 and 35,000 feet thick.

Dinosaur fragments in the Cocoraque Formation are of late Mesozoic (Jurassic or Cretaceous) age, and the upper part of the Roskruge Formation is Late Cretaceous. The lowest unit is considered to be Mesozoic because there are no known volcanic units in the Paleozoic rocks in this region.
\end{abstract}

\section{INTRODUCTION}

This report is the second of three papers, planned as chapters of U.S.G.S. Bulletin 1194, which are to define and describe briefly some of the Mesozoic Formations on the Papago Indian Reservation in south-central Arizona (fig. 1). The Papago Indian Reservation includes about 4,300 square miles, and rocks of Mesozoic age crop out extensively in the eastern two-thirds of the reservation. The area is within the Basin and Range province, in which small rugged mountain ranges are separated by broad alluviated valleys. The Comobabi (North and South) and Roskruge Mountains, which are typical of the ranges in the region, are in the east central part of the reservation. The work upon which this report is based was done as part of a geological and ground-water investigation of the Papago Indian lands made in cooperation with the U.S. Bureau of Indian Affairs. 


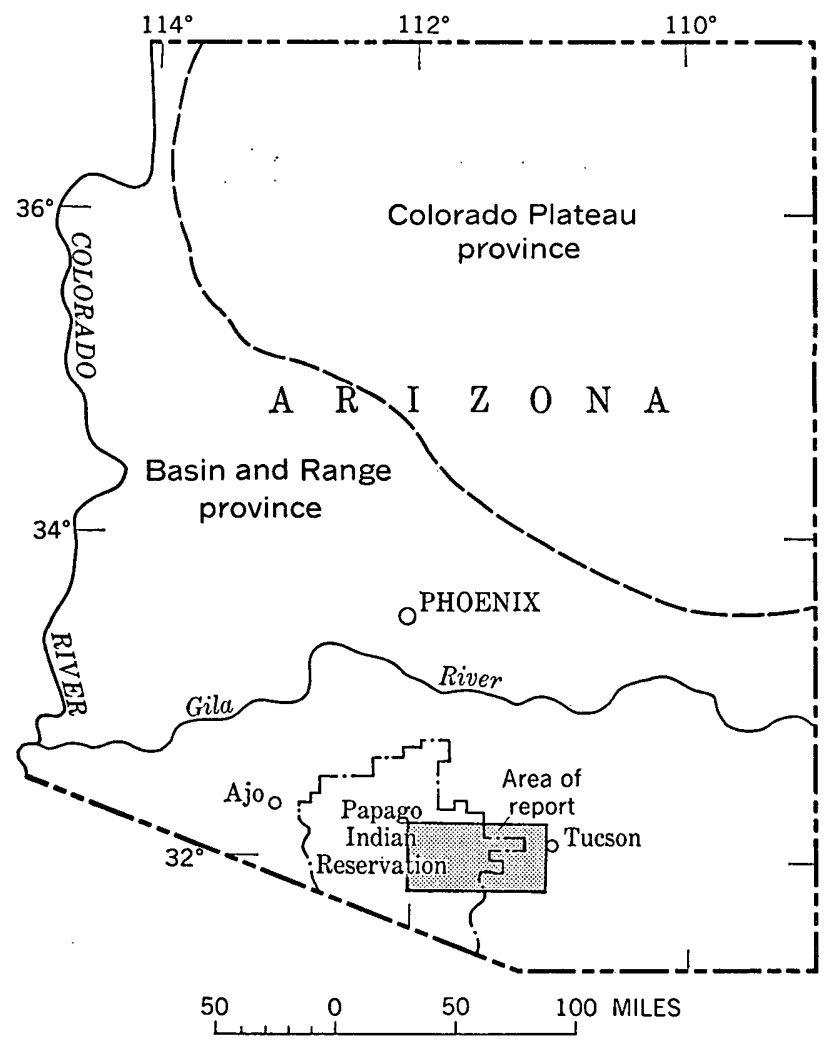

Figurg 1.-Papago Indian Reservation and area of report.

The Mesozoic rocks in the North and South Comobabi and the Roskruge Mountains (fig. 2) are more diverse than in any other part of the reservation. The post-Paleozoic and pre-Tertiary rocks include between 20,000 and 35,000 feet of sedimentary and bedded volcanic deposits, which comprise the six units described in this report, and considerable thicknesses of metamorphic rocks. Some of the metamorphic rocks may be equivalent to some of the unmetamorphosed Mesozoic units. The Mesozoic rocks are exposed discontinuously and have been folded, faulted, and intruded. The metamorphosed, and to a lesser extent the much less altered deposits described here, have been intruded by several bodies of coarse- to fine-grained igneous materials.

The sequence described here has been pieced together from evidence from different parts of the North and South Comobabi Mountains and of the Roskruge Mountains. The units, in ascending order, are the Nolia Volcanic Formation, the Cocoraque Formation, the Roadside 
Formation, and the Sand Wells Formation. The Roskruge Rhyolite and Sil Nakya Formation overlie the Roadside and Sand Wells Formations, respectively. The Nolia and Cocoraque Formations are nowhere in contact, but the Cocoraque contains volcanic pebbles from the Nolia and thus is presumed to be the younger; the superpositions of the Sand Wells over the Roadside Formation and of the Sil Nakya over the Sand Wells are presumed from structural and topographic relationships, but depositional contacts are not exposed; and the Sil Nakya Formation and Roskruge Rhyolite are presumed to be equivalent on the basis of general lithologic similarity. The inferred parts of the sequence can only be considered to be tentative, but they do appear to be consistent with structural and regional relationships.

Descriptions of the stratigraphy of the deposits in the South Comobabi Mountains are in unpublished theses by J. A. MacKallor (1958) and Leonid Bryner (1959), and the mapping, definitions of units, and rock descriptions made by these two men contributed considerably to my work. The units and sequence presented here also are based in part on stratigraphic evidence collected in other ranges of the Papago Indian Reservation by me and my colleagues on the Papago investigation, O. J. Cosner and H. G. Page; however, the responsibility for the units and sequence given in this report is mine alone.

The Mesozoic age assigned to the deposits can be supported by direct evidence only at three horizons. Two radiometric dates put parts of the Roskruge Rhyolite in the Late Cretaceous, and a few fossil fragments suggest that part of the Cocoraque Formation is of late Mesozoic age. The assignment of the lowest unit, the Nolia Volcanic Formation, to the Mesozoic, in contrast, is made largely because the Nolia is so unlike any Precambrian or Paleozoic deposits known in the region. A Paleozoic age seems unlikely for the Nolia because its volcanic rocks indicate a markedly different environment from that in which the marine limestone deposits of the upper part of Paleozoic rocks in the region were laid down and particularly because the marine environment lasted at least into late Middle Permian, or Guadalupe(?), time (McClymonds, 1959; Bryant and McClymonds, 1961; McClymonds and Heindl, 1964). Until the units are dated more precisely, I prefer a general Mesozoic age for the sequence to its more common, but possibly presumptive, restriction to the Cretaceous. ${ }^{1}$

\footnotetext{
1 See, for example, the Cretaceous and the Cretaceous and Tertiary ages assigned to these rocks on the geologic map of Pima County (Wilson and others, 1960) and by me in an earller summary (Heindl, 1960).
} 


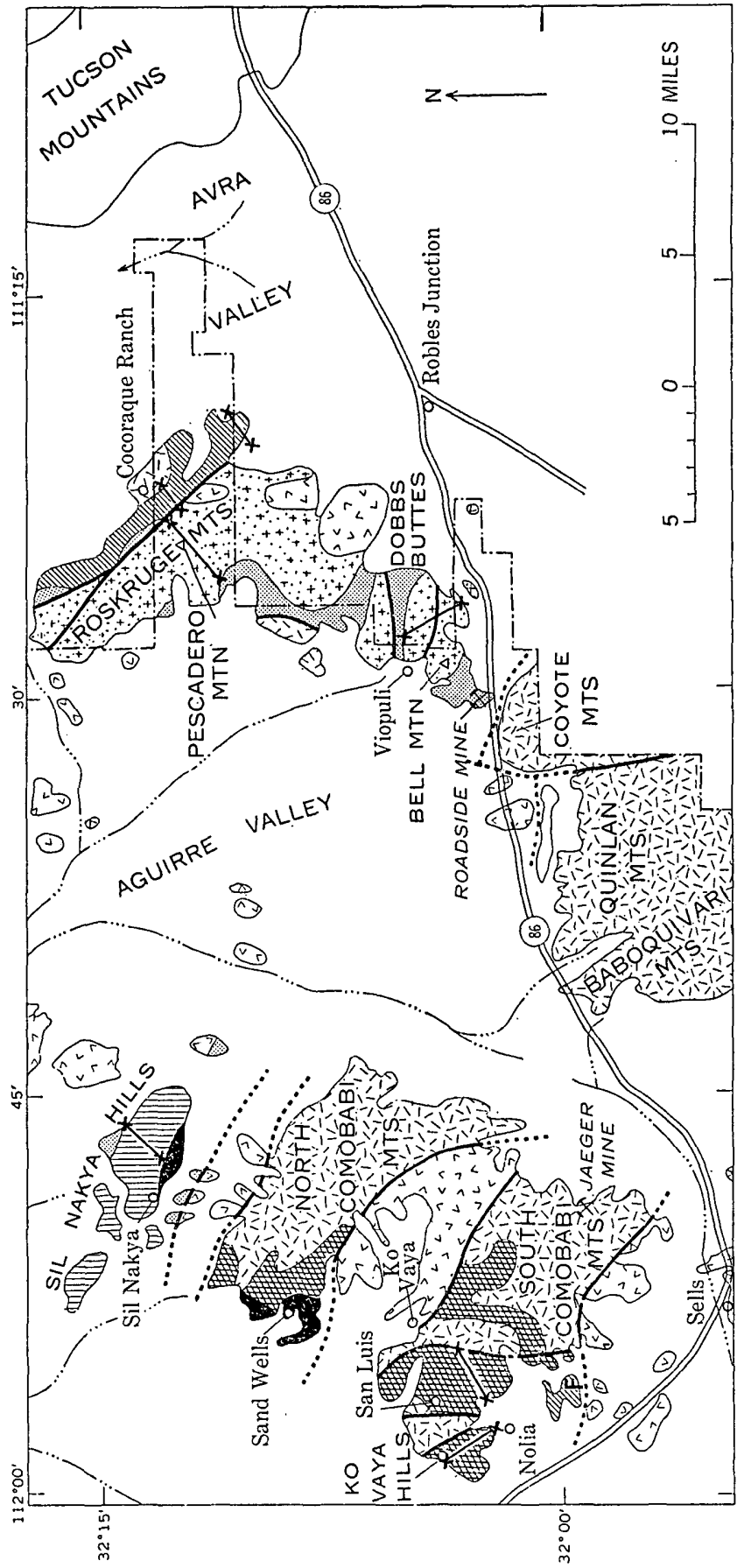




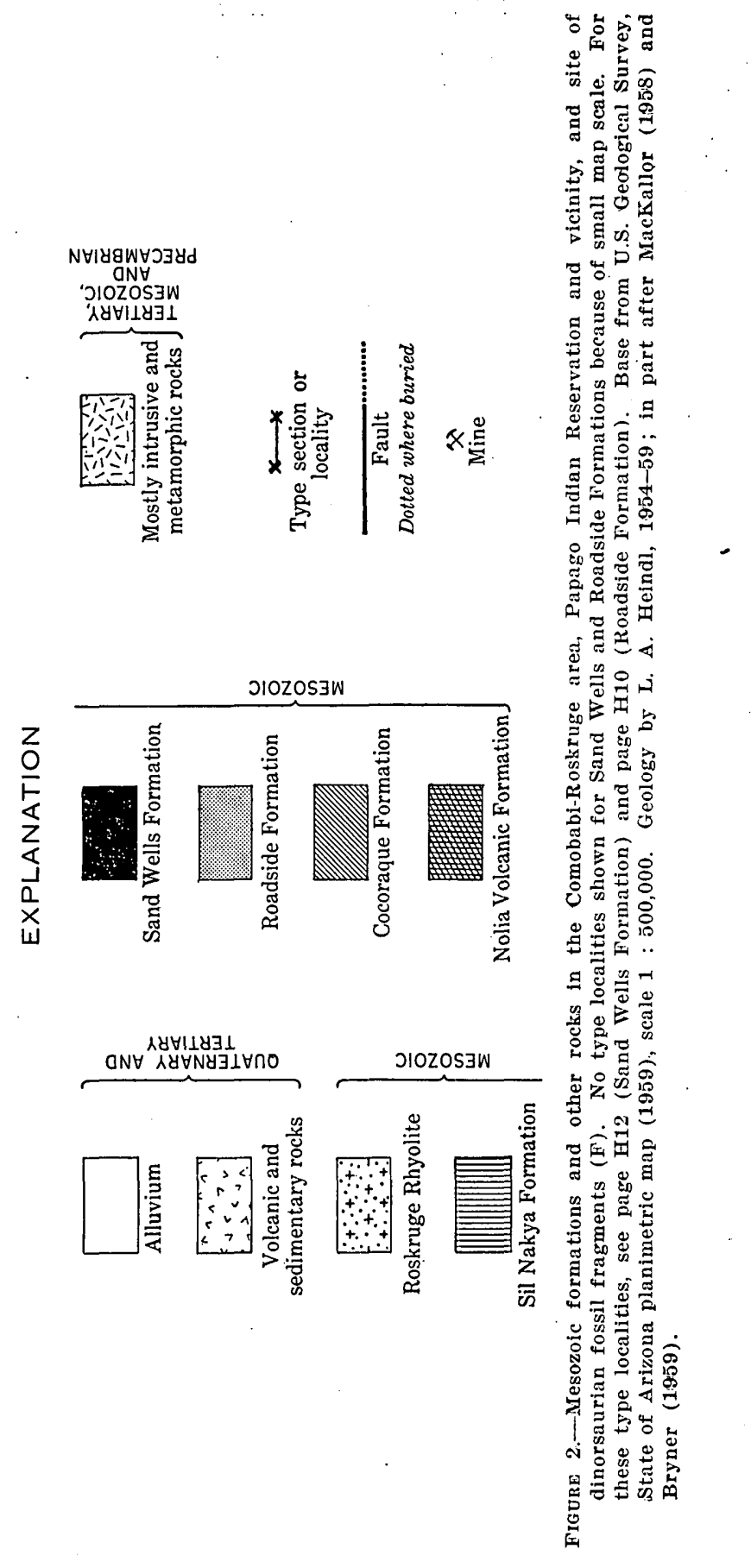




\section{OTHER ROCKS IN THE AREA}

No Paleozoic or Precambrian rocks are known to be exposed in the Comobabi and Roskruge Mountains, although their distribution indicates they were deposited in this area (McKee, 1947). The oldest rocks in the two ranges are in the southeastern part of the South Comobabi Mountains. These are phyllite, schist, and gneiss that are intruded by dioritic and monzonitic masses. The phyllite consists mostly of alternating thin beds of fine-grained hornfels and quartzite. The schist is generally fine-grained, micaceous, and epidotized. The gneiss is fine to medium grained and composed mostly of quartz, feldspar, and biotite. Locally the schist seems to grade into the gneiss. The schist and gneiss in the South Comobabi Mountains are similar to those in the Coyote and Quinlan Mountains (Wargo and Kurtz, 1956), and in all three ranges these rocks are intruded by alaskite and diorite. The alaskite and diorite in the Coyote Mountains engulf a septum of marble and quartzite which may be derived from Paleozoic rocks (Wargo and Kurtz, 1956, p. 16). The diorite in the Comobabi Mountains invades the Nolia Volcanic Formation, but not younger rocks. The unmetamorphosed equivalents of the schist, phyllite, and gneiss in the South Comobabi Mountains have not been identified. The lack of lime-silicate rocks precludes a ready correlation with the Paleozoic and younger Precambrian sections. Because the metamorphosed rocks cannot be equated with known sections, I favor the hypothesis that these metamorphic rocks are the equivalents of unidentified older postPaleozoic bedded and intrusive rocks, or possibly in part the equivalent of units described in this report.

Tertiary rocks in the area are volcanic, intrusive, and alluvial. The oldest Tertiary rocks are igneous bodies that intrude the youngest Mesozoic units. Volcanic and sedimentary deposits of probable middle Tertiary age rest on eroded surfaces cut on the Mesozoic units, and late Tertiary and partly Quaternary alluvial deposits partly fill the basins.

\section{NOLIA VOLCANIC FORMATION}

A large part of the North and South Comobabi Mountains is composed of brick-red, maroon, and black andesitic flows. These andesitic flows are here named for the village of Nolia, near which they are excellently exposed. Generally the brick-red and maroon flows are eroded to bold reddish-brown hills; the black flows weather more resdily and form dark greenish-black piedmont slopes.

The Nolia Volcanic Formation appears to overlie quartz monzonite about half a mile north of San Luis, but the contact itself was nowhere seen clearly. Bryner (1959) reports fragments of quartz monzonite in amygdaloidal basalt flows (Nolia of this report). In the central 
part of the South Comobabi Mountains, however, the Nolia Volcanic Formation is intruded by quartz monzonite. Either there were two periods of intrusion by quartz monzonite in this area, or the Nolia consists of at least two sequences of volcanic deposits separated by an interval of intrusion. The relationship of the Nolia to younger deposits is only slightly better defined. The Nolia is presumed to be older than the Cocoraque Formation, which contains fragments apparently derived from the Nolia flows. However, the Nolia definitely underlies the Sand Wells Formation on the west side of the North Comobabi Mountains.

On the west side of the South Comobabi Mountains, the Nolia Volcanic Formation comprises two distinct units, as separated in the field by MacKallor (1958) and Bryner (1959): (1) a lower sequence of predominantly dense reddish porphyritic andesitic to latitic flows and (2) an upper sequence of dark to greenish-black amygdaloidal andesite flows. In this report, however, these two sequences are mapped as a single unit because locally they interfinger. Reddish and maroon flows on the east side of the South Comobabi Mountain, similar to those of the lower sequence, are included in the Nolia because their stratigraphic position is the same, although the deposits in two parts of the South Comobabi Mountains are not continuous. Individual flows in the lower unit are usually several tens of feet thick, whereas those in the upper unit are much thinner. Sedimentary lenses, usually maroon volcanic sand and small gravel, are intercalated locally in both units. Although the reddish andesitic to latitic flows usually underlie the black andesitic flows, locally thick reddish andesitic flows are intercalated with thin black ones. The flows of the two sequences probably represent nearly contemporaneous extrusions from separate sources. The type locality of the lower sequence is along a south- to southeast-trending line through the Ko Vaya Hills; that of the upper sequence is along a southwest-trending creek that goes through the village of Nolia. (See fig. 2 for general locations.)

The Nolia Volcanic Formation varies considerably in thickness. In and near the Ko Vaya Hills, the lower unit is as much as 2,000 feet thick and the upper unit is as much as 5,000 feet thick. On the east side of the South Comobabi Mountains the reddish and maroon flows also are several thousand feet thick. In the central part of the South Comobabi Mountains, however, the formation is only a few hundred feet thick. The difference in thickness may represent post-Nolia erosion, but at least in part it probably represents thinning a way from the source areas.

The Nolia Formation is largely unaltered in the vicinity of Nolia, but in the central parts of the North and South Comobabi Mountains, 
where it has been intruded by coarse-grained dioritic and monzonitic rocks, it is partly metamorphosed. The metamorphosed rock in the vicinity of intrusive bodies can be traced through partly assimilated sections into apparently unaltered flows of the Nolia. Particularly along some washes in the North Comobabi Mountains, nearly unaltered andesite can be traced into highly epidotized fine-grained hornfels which still shows the original bedding and the amygdular porphyritic and sedimentary textures of the original rock. The volcanic flows also have been mineralized, and small lead-zinc-silver mines and prospects are common in the Comobabis. The Nolia Formation is cut by fineand coarse-grained dikes, sills, and small stocks that also cut the diorite and monzonite and younger formations.

\section{COCORAQUE FORMATION}

A thick section of folded and faulted sedimentary rocks crops out in a broad north-trending belt on the east side of the Roskruge Mountains. These beds are here named for the Cocoraque Ranch which is near the center of the area where the Cocoraque is exposed. The Cocoraque Formation forms fairly smooth steep hills whose drainage pattern suggests that they may be eroded from massive rather than from bedded rocks. Most of the hills are only faintly ribbed, although a few quartzite beds form small prominent ledges or ridges, and the hillsides commonly are littered with small splinters and spalls. Where exposed in washes, the formation stands in nearly vertical dark graygreen walls which clearly show the details of bedding and texture.

The base of the Cocoraque Formation is not exposed; the formation is presumed to be younger than the Nolia Volcanic Formation because some of the beds contain pebbles resembling the volcanic rocks of the Nolia. The Cocoraque Formation appears to underlie the Roadside Formation unconformably at a depth of 628 feet in the abandoned No. 3 shaft of the Roadside mine ${ }^{2}$ and at the surface 2 miles west of Cocoraque Ranch. The Cocoraque is intruded by quartz diorite and by fine-grained porphyritic andesite dikes. The quartz diorite is presumed to be of Late Cretaceous or early Tertiary age (Damon, 1964, fig. 2, p. 12 ; Damon, Mauger, and Bikerman, 1964), and the finegrained dikes probably are middle Tertiary.

The Cocoraque Formation consists mostly of gray-green arkose and graywacke, gray quartzite, red and gray mottled mudstone, and pebble-conglomerate beds. The unit is well bedded and well sorted, and most of the beds are less than 18 inches thick. The arkose and

\footnotetext{
${ }^{2} \mathrm{My}$ interpretation is based on core logs and written and oral descriptions provided by E. A. Stone, consulting geologist, Tucson, Ariz.
} 
graywacke are medium to coarse grained, and commonly the beds contain a sprinkling of granules or small pebbles. The quartzite is made up mostly of gray subrounded medium-sized quartz grains and a minor amount of feldspar fragments; a few quartzite beds are intensely brecciated, possibly in the vicinity of unrecognized small faults. In the central and northern exposures the conglomerate beds generally contain only small pebbles of limestone and quartzite; but to the southwest, where they predominate, the conglomerate beds also include fragments of andesitic and felsitic rocks which are assigned to the Nolia. The type localities for the Cocoraque Formation are along a northeast-trending dry creek and trail about 4 miles south-southeast of Cocoraque Ranch, and along a northeast-trending creek about 1 mile south of Cocoraque Ranch. (See fig. 2 for general locations.)

The Cocoraque Formation is folded along northwest-trending axes and is cut by numerous small faults. Its thickness is estimated to be about 2,000 feet.

Two small areas of sedimentary rocks on the southwest flanks of the South Comobabi Mountains, nearly 20 miles southwest of Cocoraque Ranch, are included tentatively in the Cocoraque Formation on the basis of lithologic similarity. The sequence here consists of about 1,000 feet of thin-bedded, commonly limey, purplish-red and olivegray mudstone, and includes sparse beds of arkosic sandstone and pebble conglomerate. The pebbles are mostly jasper and grayish-red latite. These beds are isolated from other Mesozoic units by faulting or by a cover of Tertiary flows and alluvium. The lowest beds are in fault contact with Tertiary andesite. It is particularly unfortunate that the stratigraphic relationships of these beds cannot be better defined because they are the source of the only fossil faunal fragments found in Mesozoic rocks on the reservation up to this time, as discussed below.

Near Cocoraque Ranch, and at many other places, the Cocoraque Formation is intruded by plutonic masses, commonly quartz diorite or quartz monzonite. The intrusive contact is exposed clearly in a few places, as half a mile southwest of Cocoraque Ranch. Commonly, the arkosic rocks of the Cocoraque become flinty and hornfelsic as they approach a granitoid body; the hornfels in turn grades first into a porphyritic and then into typical fine-grained and coarse-grained facies of the instrusive rock.

\section{CORRELATION AND AGE}

The Cocoraque Formation is similar to the rocks of the Amole Group of Kinnison (Brown, 1939; Kinnison, 1959), which crop out in the Tucson Mountains about 10 miles east of the Roskruge Mountains, 
but the evidence is inadequate to establish a definite correlation. The Amole is of probable Cretaceous age (Bryant and Kinnison, 1954).

The fossil fragments from the beds on the southwest side of the South Comobabi Mountains are probably Jurassic or Cretaceous (C. L. Camp, written commun., July 4, 1960). Dr. Camp reports, "Probabilities are that the material is archosaurian *** possibly late Mesozoic because of rarity of dinosaurs in pre-Jurassic beds in North America and àlso [because] dinosaurs of Triassic age so far known in North America do not have bones as large as indicated from [the] fragments."

\section{ROADSIDE FORMATION}

The Roadside Formation, here named for its exposures in the vicinity of the Roadside mine between the Coyote Mountains and Dobbs Buttes, consists mostly of volcanic conglomerate and andesitic flows and breccias. It crops out extensively in the Dobbs Buttes and Roskruge Mountains, and one small exposure about three-quarters of a mile east of the village of Sand Wells in the North Comobabi Mountains, too small to be shown on figure 2, is tentatively assigned to the Roadside on the basis of lithologic similarity. Rocks similar to the Roadside Formation are exposed at many places on and near the reservation. The Roadside Formation weathers much more readily than other Mesozoic rocks, and except where it is protected, tends to form piedmont slopes or low foothills. Commonly the Roadside Formation is dark purplish gray to shades of olive drab, and its characteristic feature is a prepondence of angular purplish andesitic fragments. The type locality for the Roadside Formation is along a line from the Roadside mine to the base of the Roskruge Rhyolite on Bell Mountain (fig. 2).

In the Roskruge Mountains, the Roadside Formation appears to be deposited unconformably on the Cocoraque Formation, but elsewhere in the area its base is not exposed. An erosional unformity is reported (E. A. Stone, consulting geologist, oral commun., 1958-59) at 628 feet below the surface at the Roadside mine. The material above the unconformity is reportedly volcanic conglomerate and that below it consists of arkose and shale. This unconformity is here interpreted to be between the Roadside and the Cocoraque Formations. In the Dobbs Buttes and the Roskruge Mountains, the Roadside Formation is overlain unconformably by tuffs and agglomerates of the Roskruge Rhyolite. In the North Comobabi Mountains, the small outcrop that resembles the Roadside, and tentatively is thus assigned, underlies the red rhyolite at the base of the Sand Wells Formation. 
The Roadside Formation comprises two generally distinguishable rock types which have been mapped separately in other areas. (See Richard and Courtright, 1960.) They are here included in a single unit because they intertongue. The lower part of the formation usually consists of dacitic flows and of poorly defined to well-defined beds of material that ranges from pebbly mudstone to boulder conglomerate and breccia. The rock fragments are derived from all the older rocks in the area. In addition to a great deal of dacitic debris, the beds contain fragments of arkosic, quartzitic, and andesitic rocks from older Mesozoic units, and fragments of limestone, quartzite, schist, and granite from Paleozoic and Precambrian sources. This lower part of the unit is the equivalent of the Claflin Ranch Formation of Richard and Courtright (1960). The upper part of the Roadside Formation consists largely of (1) poorly bedded lenses of angular to subrounded fragments of purplish gray andesite in a matrix of smaller andesitic particles and (2) andesitic breccias and flows. The upper part includes some highly brecciated 2- to 50-foot-thick limestone lenses, such as those 3 miles east of the Roadside mine, which look so remarkably like Paleozoic limestone that originally I mapped them as thrust slivers. The upper part of the unit is the equivalent of the Silver Bell Formation of Courtright (1958). Richard and Courtright (1960,p.4) summarize their description of the Claflin and Silver Bell Formations as follows: "There may have been repeated episodes of deposition of clastic and volcanics, with local intervals of erosion. Thus, the sequences may be found to differ in order and number of units from place to place. The important points are that these rocks as a group are lithologically similar over wide areas; they lie on an erosion surface cut in [older] Cretaceous and older rocks; and this surface usually marks a pronounced change in the environment of sedimentation." The description applies equally well to the Roadside Formation.

The Roadside Formation probably is several thousand feet thick in the vicinity of the Roadside mine, where steeply dipping beds are exposed nearly continuously for about $21 / 2$ miles across their strike. The amount of repetition by faulting in this intensely deformed area is unknown.

\section{SAND WELLS FORMATION}

The west side of the North Comobabi Mountains and the north central part of the South Comobabi Mountains include thick sequences of sedimentary deposits that are much like the Cocoraque and Roadside Formations except that they contain fragments of quartzite, arkose, and volcanic conglomerate that appear to have been derived from the older formations. These deposits are here named for the 
village of Sand Wells in the North Comobabis, near which they are well exposed. The Sand Wells Formation generally weathers easily and is best exposed along the walls of draws and washes. Its basal units are conspicuous because they are bright brick to purplish red. The type locality is along the wash that passes along the south side of the village of Sand Wells, and reference localities are along washes that trend north-northwest from the village and are $1 / 2$ to $11 / 2$ miles north of it. (See fig. 2.)

East of the village of Sand Wells, the basal unit of the Sand Wells Formation, a massive red rhyolite flow, overlaps slightly metamorphosed and epidotized flows of the Nolia Volcanic Formation. However, a small outcrop of what is presumed to be volcanic conglomerate of the Roadside Formation is exposed between the red rhyolite and the Nolia flows. (This exposure is too small to show on fig. 2.) Away from the North Comobabi Mountains, the Sand Wells Formation passes under Tertiary volcanic rocks and alluvium.

The formation is mostly gray quartzite, maroon mudstone, muddy sandstone, and gray-green arkose. The basal unit is a massive red rhyolite flow which is capped by a distinctive red conglomerate. The red conglomerate is composed mostly of fragments of pink to red rhyolite, but it also contains fragments of quartz monzonite, Roadside volcanic conglomerate, Nolia andesite, and Cocoraque arkose and graywacke.

In the North Comobabi Mountains near Sand Wells, only the lower 1,000 feet of sandstone and arkose of the Sand Wells Formation is exposed. Bryner (1959) reports that a section of sedimentary rocks in the South Comobabis, which here is included in the Sand Wells Formation, is at least 6,100 feet thick. But even this thickness may be minimal; the top was eroded before a fanglomerate of middle Tertiary age was deposited, and part of the section may have been cut out by thrusting. The upper half of the section in the South Comobabis includes agglomerate and volcanic breccia deposits that, although more friable and less altered, are similar to those of the Roadside Formation.

The Sand Wells Formation is cut by mafic and felsic dikes, sills, and small plugs, but it is not as extensively intruded by granitoid bodies as the Roadside and older formations.

\section{SIL NAKYA FORMATION}

The Sil Nakya Hills north of the North Comobabi Mountains are composed of a thick sequence of interbedded welded tuff, tuff-agglomerate, conglomerate, and finer sedimentary materials that are here 
called the Sil Nakya Formation. The volcanic strata form steep, fairly smooth ridges, and the sedimentary strata are exposed either in valleys between the ridges or on dip slopes. The type section is generally along a northeast-trending wash that heads 11/4 miles east-southeast of the village well at Sil Nakya. (See fig. 2 for general location.)

The Sil Nakya Formation appears to be deposited on epidotized conglomerate referred to the Roadside Formation, but the actual contact is covered by alluvial or talus deposits. The top of the formation either is in fault contact with the Sand Wells Formation or is covered by alluvium.

The basal unit is a massive lavender-gray welded tuff composed of rhyolite, quartz latite, or dacite; other welded tuff or tuff-agglomerate units are maroon to gray and all contain sand- to granule-sized fragments of clear quartz. The welded tuff units are from about 400 to 2,000 feet thick. A fow andesitic or basaltic flows are interbedded with tuff deposits near the middle of the section. Intercalated sedimentary deposits include maroon mudstone and sandstone, tuffaceous sandstone, and thin conglomerate lenses. The top unit, however, is a 1,000-footthick brown pebble-to-boulder conglomerate having fragments of welded tuff and agglomerate from the underlying units of the Sil Nakya, and fragments of maroon andesite that may be from the Nolia.

The Sil Nakya Formation is at least 8,000 feet thick, of which 6,400 feet is welded tuff.

The Sil Nakya probably is equivalent to the Roskruge Rhyolite, inasmuch as their welded tuffs are lithologically similar, although the number, order, thickness, and types of units in each formation are distinctive and the two formations both appear to overlie the Roadside and to be older than the oldest known Tertiary rocks in their vicinities.

\section{ROSKRUGE RHYOLITE}

The central part of the Roskruge Mountains, most of the Dobbs Buttes, small patches in nearby ranges, and isolated hills are composed of a variable sequence of rhyolitic flows, tuffs, agglomerates, and intercalated sedimentary lenses and dacitic or andesitic flows. This sequence is here named for its exposure in the Roskruge Mountains, the type locality. Where appropriate, the Roskruge Rhyolite is divided into the Pescadero Member, composed predominantly of flows and here named for Pescadero Mountain in the Roskruges, and the Dobbs Buttes Member, composed predominantly of pyroclastic rocks and here named for its exposure in the Dobbs Buttes. Where the Roskruge is composed of intertonguing flows, and pyroclastic and sedimentary units, it is not subdivided. The flows form rugged hills characterized by steep slopes and cliffs; the pyroclastic deposits weather to steep slopes or cliffy buttes and hills which display pinkish- 
orange, yellowish, greenish, and buff bands. The type locality of the Pescadero Member of the Roskruge Rhyolite is along a general northeast-trending line through Pescadero Mountain. The type section of the Dobbs Buttes Member of the Roskruge. Rhyolite is along a southtrending line through the main peaks of the Dobbs Buttes. (See fig. 2 for general locations.)

The Roskruge Rhyolite rests on tilted beds of the Roadside Formation and older deposits and is overlain unconformably by late Tertiary volcanic and alluvial deposits.

The rhyolite flows commonly are pinkish to reddish gray and are characterized by a high proportion of granule- to small-pebble-sized phenocrysts of quartz; some units, however, are nearly aphanitic. The flows are lenticular and range from a few tens to about 300 feet in thickness. In the central part of the Roskruge Mountains, which is made up mostly of flows, the Roskruge Rhyolite may be as much as 4,000 feet thick. In the Dobbs Buttes, the rocks are mostly pyroclastic and sedimentary, and the Dobbs Buttes Member is about 1,250 feet thick: Here the lowest unit, except for thin local lenses of basal conglomerate, is a 50-foot-thick grayish-purple to brown tuff-agglomerate; this unit is similar to the lowest unit exposed in the Roskruge Mountains at several points. The Dobbs Buttes Member includes grayish-green dacite flows which were not seen in the Pescadero Member in the Roskruge Mountains. The flows and pyroclastic deposits are interbedded with thin water-laid tuffaceous sediments and with sandstone and pebble conglomerate beds.

Because units of the Pescadero and Dobbs Buttes Members intertongue, and because their basal members in their type localities are similar, they are believed to be generally equivalent.

\section{CORRELATION AND AGE}

The age of the Dobbs Buttes Member of the Roskruge Rhyolite has been determined at two points. Both dates are from Bell Mountain, a hill made up largely of Dobbs Buttes rocks. A welded tuff near the base of the section, listed as the "Viopuli red ignimbrite," and "the immediately overlying dense welded tuff" are dated radiometrically at about 74 and 71 m.y. respectively (Damon, 1964, p. 21). These dates indicate the Dobbs Buttes Member of the Roskruge Rhyolite is Late Cretaceous, and they compare with radiometric dates of about 66 to 70 m.y. (Bikerman and Damon, 1964, table 1) for the lithologically similar Cat Mountain Rhyolite of Brown (1939) in the Tucson Mountains, about 20 miles to the northeast. On the basis of lithologic similarity and of close approximation of the radiometric dates, the Roskruge Rhyolite is tentatively considered to correlate with the Cat Mountain Rhyolite. 


\section{REFERENCES CITED}

Bikerman, Michael, and Damon, P. E., 1964, K/Ar chronology of the Tucson Mountains, Pima County, Arizona, in Correlation and chronology of ore deposits and volcanic rocks: Tucson, Arizona Univ. Geochronology Lab., June 1, 1964, p. AII 1-12.

Brown, W. H., 1939, Tucson Mountains, an Arizona basin range type: Geol. Soc. America Bull., v. 50, p. 697-759.

Bryant, D. L., and Kinnison, J. E., 1954, Lower Cretaceous age of Amole arkose, Tucson Mountains, Arizona [abs.]: Geol. Soc. America Bull., v. 65, no. 12, pt. 2, p. 1235.

Bryant, D. L., and McClymonds, N. E., 1961, Permian Concha Limestone and Rainvalley Formation, southeastern Arizona: Am. Assoc. Petroleum Geologists Bull., v. 45, no. 8, p. 1324-1333.

Bryner, Leonid, 1959, The geology of the South Comobabi Mountains and Ko Vaya Hills, Pima County, Arizona : Arizona Univ. unpub. doctoral dissert., $156 \mathrm{p}$.

Courtright, J. H., 1958, Progress report on investigations of some CretaceousTertiary formations in southeastern Arizona: Ariz. Geol. Soc. Digest, 1st Ann., p. 7-9.

Damon, P. E., 1964, Summary of research accomplishments in Correlation and chronology of ore deposits and volcanic rocks: Tucson, Arizona Univ. Geochronology Lab., June 1, 1964, p. 4-28.

Damon, P. E., Mauger, R. L., and Bikerman, Michael, 1964, K/Ar dating of Laramide plutonic and volcanic rocks within the Basin and Range province of Arizona and Sonora in Correlation and chronology of ore deposits and volcanic rocks: Tucson, Arizona Univ. Geochronology Lab. Contr. 91, June 1, 1964, p. AI 1-12.

Heindl, L. A., 1960, Cenozoic Geology of the Papago Indian Reservation, Pima, Maricopa, and Pinal Counties, Arizona (a preliminary summary) : Arizona Geol. Soc. Digest, v. 3, p. 31-34.

Kinnison, J. E., 1959, Structure of the Saginaw area, Tucson Mountains, Arizona, in Arizona Geol. Soc. Guidebook 2, April 1959: Arizona Geol. Soc. Digest, 2d Ann., p. 146-151.

McClymonds, N. E., 1959, Precambrian and Paleozoic sedimentary rocks of the Papago Indian Reservation, Arizona, in Arizona Geol. Soc. Guidebook 2: Arizona Geol. Soc. Digest, 2d Ann., p. 77-84.

McClymonds, N. E., and Heindl, L. A., 1964, Stratigraphic sections of younger Precambrian and Paleozoic formations, Papago Indian Reservation, Arizona : U.S. Geol. Survey open-file rept, 118 p., 5 figs.

MacKallor, J. A., 1958, Geology of the western part of the Cobabi mining district, Pima County, Arizona : Arizona Univ. unpub. master's thesis, $108 \mathrm{p}$.

McKee, E. D., 1947, Paleozoic seaways in western Arizona : Am Assoc. Petroleum Geologists Bull., v. 31, p. 282-292.

Richard, Kenyon, and Courtright, J. H., 1960, Some Cretaceous-Tertiary relationships in southeastern Arizona and New Mexico : Arizona Geol. Soc. Digest, v. 3, p. 1-7.

Wargo, J. G., and Kurtz, W. I., 1956, Geologic and tectonic features of the Coyote Mountains, Arizona: Ohio Jour. Sci., v. 56, no. 1, p. 10-16.

Wilson, E. D., Moore, R. T., and O'Haire, R. T., 1960, Geologic map of Pima and Santa Cruz Counties, Arizona: Tucson, Arizona Bur. Mines, scale $1: 375,000$. 